\title{
Can't Help Lovin': David Chidester's Pop Culture Colonialism
}

\author{
Kathryn Lofton \\ kathryn.lofton@yale.edu
}

'As we have seen, a frontier is a zone of conflict, but it can also be a zone of reciprocal exchanges, creative interchanges, and unexpected possibilities'

(Chidester 1996a:266)

\begin{abstract}
This article examines the likability of hip-hop star Kanye West and The Voice champion Jordan Smith to explain the colonial terms for our pop culture taste. The writings of David Chidester establish the tie between religion and colonialism as an axiomatic one; he also argues that popular culture is a rich site for formations of religion. West and Smith offer an opportunity to argue the connection between these two strands of scholarly observance, showing the fractal effects of colonialism in Africa on the preferences of pop culture consumption in America. The attraction to West's unlikability is the other side of the easy adoration for Jordan Smith: like those colonists who gave religion to those colonized subjects they dominated, pop consumers refuse to admit their intimate and needful connection to those idols who resist their control. Although organized by particular instances, this article seeks to encourage those in pop culture studies to see the erotic work of dislike; it seeks to encourage those in religious studies to see how pop subjects carry forward the classificatory imprints of colonial frontiers.
\end{abstract}

Keywords: colonialism, hate crime, hate watching, Jordan Smith, Kanye West, popular culture, religion, whiteness 


\section{Introduction}

David Chidester established the study of religion as inextricably linked to the history of colonialism. One cannot think of 'religion' without also thinking about those who defined it on settler frontiers. For Chidester, religion is a category that does not belong solely to the academy, but it is 'constantly at stake in the interchanges of cultural discourses and practices' (Chidester 1996a:745 $)^{1}$. Academic thinkers have a part to play in these interchanges, but they are not alone, and their work is inconceivable without colonial territories.

The majority of Chidester's bibliography focuses on the African frontier. Yet his 1996 article evinces a secondary strand of interest in American popular culture and its peculiar relationship to religion. He has never written at length about how he understands the relationship between these two subjects. This article seeks to demonstrate the interrelation between colonialism in Africa and the pop culture in America. In tribute to Chidester's gift for weird examples, I will not do this in the most obvious or easy way by exploring representations of African culture in American culture ${ }^{2}$. Instead, I take a roundabout route, pursuing an odd comparison: An American winner of The Voice, Jordan Smith, and an American hip-hop artist, Kanye West.

This article aims to understand Kanye West through a critical assessment of the colonial apparatus from which he emerged and of which he is a constitutive component. Given his political presence since the 2016 election, for some readers it may be discomfiting to read an account of West that does not focus on diagnosing his mental illness or indicting his relationship to Donald Trump. Yet I have learned from the writings of David Chidester that our job as scholars is to think hard about the fractal consequences of colonialism. Included among those consequences is the present-day ways that race functions in popular culture. I do not offer an exhaustive consideration of the entirety of Kanye's career or the global phenomenon of The Voice. Rather,

1 This is also published as chapter 2 of Chidester's book Authentic fakes: Religion and American popular culture (Chidester 2005).

2 Such a study might look like Black Africans in renaissance Europe (Earle \& Lowe 2005) or Representing African Americans in transatlantic abolitionism and blackface minstrelsy (Nowatzki 2010), and it might achieve the sort of conclusions found in Representing African music (Agawu 1992) or Representing Africa in American art museums: A century of collecting and display (Bickford \& Clarke 2011). 
through a comparison of two public pop figures, I want to underline how the particularly colonial inheritance of race determines our liking for pop things. This is intentionally written as a riff on that critical space which the jazzinfused writings of David Chidester inspire me to take. I seek to honor Chidester's work not only through the focus on continuing an arc of his thought, but also the modality of my comparative and ranging discussion.

Jordan Smith and Kanye West offer the opportunity to think about what makes a certain genre go global. The Voice is a television singing competition which has, since its origin in 2011, been adapted in 145 countries or regions. Hip-hop is a style of popular music dating from the 1970s and originating in black and Hispanic communities of the United States and now defining musical expression from Brazil to Beijing, from Senegal to Saudi Arabia. Hip-hop is rap with a musical backing: It is defined by the rhymes of its spitting artists and the production that situates their riffs in a specific sonic shape. Reality TV singing competitions rarely include rap and tend to default in simple backdrop music to accompany the karaoke-style cover choices of the competing contenders. Hip-hop artists get famous for what they say and how people cannot stop bobbing their head with them. Reality TV competitors get famous for singing the songs of others in a way that makes people vote for them over other hopefuls. In both genres there is a form that the culture can occupy so that the global becomes immediately local: There is an La Voz Mexico and The Voice Thailand, Japanese hip-hop and Nigerian hip-hop.

Whether in Moscow or Mexico City, these forms of music become successful when people attach their liking to the artists. The audience needs to vote for a reality TV contestant and needs to buy the albums of the hip-hop star; they need to like what they hear. It is the nature of that liking that interests me, and the relationship between versions of like and the histories of colonialism that give rise to the genre. 'America's most original contributions to popular music - jazz, blues, rock, rap, and hip-hop - originated in Africa', David Chidester (2005:150) explains. He then works hard to dispel the persistent notion that there is a genealogy of popular American music in which its rhythms offer a porthole to African religion. Instead, he demonstrates that the history of popular American music is not a history of African cultural origins and African American cultural survivals; he rather shows that throughout the $20^{\text {th }}$ century there were ongoing exchanges between Africa and America that produced different forms of intercultural subjectivity and collectivity within religion and popular culture. Even when no actual exchange 
of a person or album between Africa and America took place, the memory of Africa defined much of the musical choices of innovating musicians (Chidester 2005:170).

Using Chidester's work, I want to assert that the intimately interpretive and comparative dynamic of colonial Africa is a conceptual backdrop to American popular culture. This is not a neatly joyful commemoration. Popular culture is not only about affirming something through one's happy liking of it; it is also about liking the bad feelings something elicits from a person and liking feeling those badfeelings. Discomfort with and dislike of other people organize settler frontiers. It is also critical to the popularity of the cultures that descend from those same intercultural frontiers of exchange. This is how the history of colonialism feeds, connects to, and comprises the present-day affective structure of pop consumption: People define who they are not only by what they love, but also by what they do not love. To understand the present-day pop cultural, one needs to know the features of the pop culture colonialism that David Chidester has spent a career describing and defining. I conjure this neologism 'pop culture colonialism' to summarize how Chidester conceives of the role of culture in the insistence of empire.

\section{Pop culture colonialism}

In regular academic application, colonialism tends to refer to the extension of one nation's sovereignty over a territory beyond its borders. Colonizing nations often seek total control over the resources of that territory. This control is established through settler colonies, including administrative offices, educational institutions, and missionary operations. If colonialism is the direct intervention of a nation upon countries not in its established borders, imperialism refers to the more indirect routes of control, such as the forms of linguistic, religious, and social coercion that emerge from administrative offices, educational institutions, and missionary operations. Imperialism is the authority of influence and market pervasion; colonialism is the authority of overt political, military, and institutional control. Although often the result of economic need, colonialism is almost always publicly justified through an ideology of paternalistic superiority in which the colonizer is convinced that they have something to offer the colonized. This 'something' is usually the full 
imperial package of better societies, better markets, better schools, and better gods.

David Chidester enters this definitional frame. He does two things to this account: First, he amplifies the role of the colonized to observe how they function in dialogue with the colonizer; and second, he observes how the concept of religion is a definitional to the gradual hermeneutic process by which domination transpires. 'As we review the history of the study of religion', Chidester (2014:312) explains, 'it is necessary but not sufficient to assert that the general idea of religion is a constructed category and that all kinds if ideas about specific religions have been invented' (emphasis added). In the case of occupied Africa, several different ideas about religions were invented, and - as he repeatedly demonstrates - this invention was never a onesided proposition. Colonized subjects were always finding ways to squeeze between the cracks of dominating systems in order to twist the disciplining particulars and claim forms of authority. Describing this dialectic is a consistent subject within every work by Chidester: He wants his readers to know that nobody in any place in human history ever said a simple 'yes' to the classification affixed over their name, their tribe, their community, or their culture. Individuals squirm beneath subjection and will not let themselves stay so conceived.

To summarize, Chidester sees on the colonial frontier a three-part hermeneutic process: First, the colonizers observe the colonized, and describe them as possessing no religion; second, the colonizers observe the colonized further, and produce a raft of information about their local culture, comparing the colonized against the colonizer in an effort to prove morphological commonalities while retaining hierarchical distinctions befitting a developmental rendering of human difference; and third, the colonizers decide the colonized have a religion, and that they can practice that religion, as long as it remains within the bounds described in their definition. This sequential process mirrors the plot of material domination itself; the less the colonizers feel to be in total control of the local population, the less religion they designate to the colonized. The more the colonizers control the colonized, the more the colonized are allocated a religion. Frontier comparative religion was, in Chidester's brilliant framing, 'a human science of local control' (Chidester 1996a:2). Before coming under colonial subjugation, Africans had no religion. Once the colonizers came, they began to capture interpretively the observed territorial communities in ways to make them 'coherent, integrated, and 
bounded' in distinct cultures and communities (Chidester 1996a:3). After these communities had been so bundled, local religious systems could be described; therefore, 'the discovery of local religious systems in southern Africa can be precisely correlated with the establishment of local control over Africans' (Chidester 1996a:3).

I will now move from Chidester's encapsulation of colonial modernity to $21^{\text {st }}$-century icons of a late settler colonial empire. As I do this, I want to retain the memory of this circuit. I want to recall how much emphasis Chidester places on the first stage - on the denial of religion - in the establishment of colonial strength. This 'long history of denial' will produce 'a multilayered discourse about otherness that identified the absence of religion with images of indigenous people as animals or children, as irrational, capricious, and lazy, as both blankness and barrier to European interest' (Chidester 1996a:20). To be clear: I am interested in how this kind of designation is a kind of obsessive dislike. The colonizer cannot stop looking at the indigenous and cannot stop labeling that looking as a comparative lack. Their liking is a dislike that is a liking. As we turn now to Jordan Smith and Kanye West, I want us to think about the figures - national and international - that capture our attention. How are the things that unite us also, now, a form of global control? How is our liking itself a taste not wholly in our hands, coerced through authorities that interpret on our behalf? And where are the cracks into which the dialectic can squeeze?

\section{Liking in popular culture}

I observed that Chidester has not explicitly examined the connection between colonial Africa and American popular culture. This is not exactly right. He does briefly suggest their connection, focusing on the kinds of comparative work people do when looking at themselves relative to others. 'The study of religion and religious diversity can be seen to have originated in the surprising discovery by Europeans of people who have no religion', Chidester (1996b:759) has written.

Gradually, however, European observers found ways to recognize by comparison, by analogy, and by metaphoric transference from the 
familiar to the strange - the religious character of beliefs and practices among people all over the world. This discovery did not depend upon intellectual innovations in defining the essence of religion, it depended upon localized European initiatives that extended the familiar metaphors that were already associated with religion, such as the belief in God, rites of worship, or the maintenance of moral order, to the strange beliefs and practices of other human populations. In the study of religion in American popular culture, I would suggest, we are confronted with the same theoretical dilemma of mediating between the familiar and the strange (Chidester 1996b:759).

To begin this particular act of comparison, I want to contrast two video clips that mark the entrance of specific figures, Smith and West, into the pop stratosphere. In one, a contestant in The Voice begins to sing. As with every contestant's blind audition, the judges initially cannot see them; all they hear is the voice. If they decide the voice is good enough for them to coach, they press a buzzer and swivel around, allowing them to see the contestant. The camera work of the show follows the movements of the judges, not revealing the appearance of the singer to the home audience until one of the judges decides their voice is worthy of potential investment. In this now-famous blind audition, the voice is a dulcet androgynous one covering Sia's pop hit, Chandelier - a song that has a quick beat but a poignant lyric in which the singer is relating their rationalization of their partying, possibly alcoholic, life. In the video one watches as the four coaches listen with interest and then, in quick order, all press their buzzers, revealing, as they swivel, a smooth-faced portly white man with a conservative haircut and large glasses singing his heart out in a cardigan and plaid shirt (The Voice 2015). The judges' shock, as well as the audience's, is palpable: How did this smooth extraordinary sound come from that person?

The second video is also one drawn from a televised music event: It is from an award presentation at the 2009 MTV Video Music Awards. In it, two lesser celebrities give the award for Best Female Video to pop star Taylor Swift. She, shocked in a way familiar to her fans who have seen her frequently experience surprise at winning awards, goes to the stage to make a few 'oh gosh, I can't believe it' comments. She is a tall, thin, white female, and blonde American in a sparkling column white sequined dress. She offers a few sentences of gratitude, thanking everyone. Suddenly a man comes up to the 
stage, perhaps from backstage. He is a black American in a black top wearing black sunglasses. He grabs the mic from her, and says, 'Hey Taylor, I'm really happy for you, and I'm going to let you finish, but Beyoncé had one of the best videos of all time. One of the best videos of all time!' The man hands the mic back to Swift, who now awkwardly holds it at an angle, uncertain as to whether the award she had just received is still hers (Alessandro 2013). The man is Kanye West.

Each text introduces its surprise subject differently. The first appearance is a typical exhibition of wonder: The voice from the sky brought down to earth. The second is a stereotype come to national life: The black man offends the white woman as she goes about her daily business of winning. In each instance there have been many internet views of the disruptive moments their star individuals create. Let us look at the content of the liking of both the videos, insofar as millions of views evince some notion of 'liking' more deeply.

Jordan Smith, a 21-year-old The Voice contestant from Harlan, Kentucky, attended an evangelical college in Tennessee. From his first moment on national television, Smith produces an aesthetic confusion. His genderless and expansive voice cannot quite be reconciled with his physicality. Why are the judges and the audience so shocked? We assume it is his embodied form: Pale and doughy, a bit hunched, wearing glasses that contract his eyes into wetlooking seeds (to quote Showler, a culture reporter). At his first audition, The Voice coaches asked if Smith would mind 'sharing his story'. 'Obviously, my voice is different,' Smith said, 'I've had to learn that being different is actually what makes me special. It's my gift. This is an amazing opportunity to share that it's okay to be different, and it's okay to be yourself. Because you're made that way, and that's how God intended you to be' (Showler 2015).

If the turn to God seems odd, it is not. The Voice is no stranger to such religious messaging, starting with its title. In the Hebrew Bible and New Testament, references to the disembodied voice of God proliferate, almost always with a remark upon the profound quality of its sound. Across geographies and throughout recorded history, sounds from invisible sources have been attributed to heavenly sources. The entire setup for The Voice reenacts this trope, in part to negate the inevitable prejudice visual cues can foster. 'People may be unlikely to recognize or admit that visual displays can affect their judgment about music performance, particularly in a domain in which other signals are deemed to be more indicative of quality', cognitive 
scientists have explained, showing how the visual can dominate our decision making, no matter the other available sensory data (Tsay 2013). The Voice allows everyone to be seen for their spirit, first, and their physical person, second. However, these are not the only religious invocations on the show: Many contestants of The Voice profess to having developed their instruments, singing in their church choirs, and the language of 'being saved' abounds in the moments when contestants know they will not be cut.

Note how an evangelical culture slips into the secular of a network singing competition without a scrape or a smudge. See how easy it is to make something secular into something evangelical, and something evangelical into something secular. This is neither the dualist evangelicalism of the Left Behind series in which everyone you meet is categorized into the saved and the damned, in which dehumanization is a required feature of Christian practice, nor is this the friendly pastor using the Da Vinci Code in an Easter sermon to draw the congregation into listening (Haskell, Paradis \& Burgoyne 2008:139156). This is something else.

In a 2016 article called Domesticating otherness: The snake charmer in American popular culture, Racy states: 'Alienness takes many forms. The very concept of charming...tends to connote magic, a phenomenon assumed to exist beyond the rational realm '(Racy 2016:199, 200). As Racy explains, the very notion of charming through music is quite familiar to Westerners. Often cited is the proverbial adage, 'music has charms to sooth a savage beast'. The use of music to placate supernatural beings appears in Greek mythology; recall the story of Orpheus using his lyre to charm the gods of the underworld in order to bring back to life his wife, Eurydice, who - interestingly, in this case - had died of a snakebite. In the North American Pentecostal ritual of snake handling, the participants individually hold one or more different poisonous snakes, while dancing to highly buoyant musical accompaniment, believing that their strong faith will empower them to evade the snake bites or to overcome their lethal effect. The snake charmer, the lyre-playing charmer - these are exotic images. In the West, exoticism has embraced various, often oppositional, attitudes toward the 'other', wanting the 'other' to be both empty-headed and wholly dangerous, ignorant and wily. Interpreting Jordan through this divided tradition, one can see him, simultaneously, as an alienated dorky everyman and a potentially marginalized white man. Who is Jordan charming when he sings? Who does he slay with his unidentifiable sound? 
In his rumination on what 'black' is in 'black popular culture', Stuart Hall makes this observation: 'I have the feeling that, historically, nothing could have been done to intervene in the dominated field of mainstream popular culture, to try to win some space there, without the strategies through which those dimensions were condensed into the signifier "black" (Hall 1993:110).

Kanye's disruptions might thereby be seen as his practice of blackness: $\mathrm{He}$ is the person one has already decided him to be. However, disruption is what he has come to epitomize in his role as an artist who treats celebrity as one of his artistic mediums. This is demonstrated clearly in the moment when Swift was giving her acceptance speech for her video, 'You belong with me' (Swift 2009). West leaps onto stage and interrupts her, stating that Beyoncé had a better video. West references Beyoncé's music video for 'Single ladies (put a ring on it)' (Beyoncé 2009). As West stands onstage, the cameras cut to Beyoncé, who looks shocked, and we can see her saying, 'Oh, Kanye. Oh, God' (Alessandro 2013). She loves him, she is worried about what he is doing. Meanwhile, West is booed by the audience.

Later we learn that backstage Swift was seen hysterically crying. According to Rolling Stone (Kreps 2009), when her mother confronted West about his interruption, he gave 'a half-hearted apology in which he added he still thought Beyoncé's video was superior' (Kreps 2009). After Beyoncé won Video of the Year for 'Single Ladies' later in the same award show, she acknowledged her experience winning her first VMA with Destiny's child at the age of 17, and called Swift back to the stage, hugged her, and let her finish her speech. During the commercial break, singer Pink walked by West and reportedly shook her head in disgust. West was later removed from the remainder of the show. He subsequently wrote an apology on his blog (which he later removed). Various celebrities and industry figures spoke out about the incident through Twitter and other outlets, condemning West for the verbal outburst. Then real estate mogul, Donald Trump, called for a boycott of Kanye West (Kreps 2009).

Who was the victim in this crime? Many said Taylor was, focusing on the masculinist bullying of Kanye's actions. Others said Beyoncé was, focusing on her repeated dignity in the context of losing awards. Nobody could imagine that Kanye could be a victim. He was the perpetrator, the unlikable one. Several years later, an interviewer would ask then President Barack Obama: 'Kanye or Jay-Z'?, whereupon Obama answered definitively: 'Jay-Z'. The interview continued: 
'Although I like Kanye', Obama continues, with an easy smile, 'he's a Chicago guy. Smart. He's very talented'. He is displaying his larger awareness of the question, looking relaxed, cerebral but friendly, alive to the moment, waiting for me to get to the heart of the matter.

'Even though you called him a jackass'?, I ask.

'He is a jackass', Obama says, in his likable and perfectly balanced modern-professorial voice, 'but he's talented' (Samuels 2012).

This is the basic conclusion about Kanye. He is a talented person, but he is a jackass: He assaults a white woman onstage and coopts every moment for his message. The question is whether his crime against Taylor Swift was precisely assault, and if it was, what kind? Was it a hate crime? In the popular rendering of hate crimes, they are a form of 'stranger danger', i.e. a random act, involving a perpetrator and victim who are complete strangers to each other. This image of the criminal as a stranger has been effectively challenged in a number of empirical studies. These studies indicated that in only a very small number of crimes $(5 \%)$ the perpetrator was a stranger to the victim. The same study found that 90 percent of the incidents took place near or at the victim's home and 10 percent took place near or at the victim's workplace. In short, as with recorded allegations of hate crime as a whole, recorded allegations of racial and homophobic harassment take place in locations that are very much a part of the victim's daily life and ordinary activities, or, as Stanko, Kielinger, Paterson, Richards, Crisp \& Marsland (2003:31-32) put it, ' $[\mathrm{H}]$ atred is often found closer to home and too often directed at the intimate partner, neighbor, friend or acquaintance'. Watching Kanye on a stage intervening upon an equally elite star in the celebrity firmament, one is struck by the intimacy of the trio, of Taylor, Kanye, and Beyoncé. In violence, in colonialism, in hate, intimacy is the frame in which the worst transgressions occur. We do the worst kind of things against servants and wives, neighbors and friends.

The term 'hate crime' refers to criminal behavior motivated by prejudice. In this sense, the term 'hate crime' is a bit of a misnomer: It may not be obvious that prejudice itself is a form of hate. Generically hate crime is meant to distinguish criminal conduct motivated by prejudices from criminal conduct motivated by other hateful feeling (lust, jealousy, greed, etc.). Unlike theft, burglary, or assault, hate crime emphasizes the offender's attitudes, values, and character (Jacobs \& Potter 1997:2). If we consider this element of a hate crime's diagnosis, we may broaden the potentially indicted: Who in this 
scene is the most prejudiced - Kanye or Taylor? This may seem a bit of a leap, even a bit of victim blaming. After all, Taylor was the one who was embarrassed, as she was the woman who was interrupted by a man yelling about another woman on an international broadcast. However, I seek to see what Chidester would ask us to see - the colonial histories that shaped that onstage encounter between superstar and superstar, black man and white woman.

\section{Racial hate in popular culture}

The history of the United States is a lengthy and bloody story of European invasion and the systematic domination and subjugation of non-European peoples. The creation of white European privilege was brought about by means of invasion of the Americas and the taking of social, economic, and political power by force from indigenous subjects and through the use of enslaved labor. In a book titled Internal colonialism, Michael Hechter argues that once privilege was wrested by force, it becomes institutionalized: 'The superordinate group, now ensconced as the core, seeks to stabilize and monopolize its advantages through policies aiming at the institutionalization and perpetuation of the existing stratification system' (Hechter 1975:39). This stabilization of stratification is also known as institutional discrimination; institutional discrimination is built into the existing structure of societal institutions such as schools, banks, and hospitals (Martinez 1997:266). Institutional discrimination in this sense is just a continuation, a further gentrification, of colonial forms of administration, education, and incarceration.

On September 2, 2005, four days after Hurricane Katrina hit New Orleans with devastating impact, NBC gathered celebrities from TV, film, and music to raise money for the victims. A concert for hurricane relief drew 8.5 million viewers and raised a reported $\$ 50$ million, but that is not what, ten years later, this telethon is remembered for. Instead, the benefit, hosted by then NBC mainstay morning journalist, Matt Lauer, and featuring the Hollywood actors, Leonardo DiCaprio, Claire Danes, Glenn Close, and Lindsay Lohan, will go down as an important page in the Katrina story for one moment: When Kanye West, channeling a nation's frustration at the federal government's failure to 
help storm victims, looked straight into an NBC camera and said, on live TV, 'George Bush doesn't care about black people'. In this instance, West again disrupted a pop genre (here, a telethon). Like the moment at the VMA awards, he made discrimination a subject of pop attention. 'I hate the way they portray us in the media', he said. 'You see a black family it says they're looting, and if you see a white family they are looking for food'. He related many of the people who could help were elsewhere at war, and that the military had been given permission to shoot black people. He then stated that he would ask his business manager how much he could feasibly give the Red Cross to help in their relief efforts (West 2006).

In the years since, West stood by his remarks and George W. Bush called it the 'all-time low' point in his presidency. West subsequently expressed his regret, and Bush forgave him (Chappell 2010)). Comedian Mike Myers, who stood in bewilderment alongside West as he went wildly off script, now says that he agrees with the essential message - that the government would not have failed a wealthier city with more white people in the same way - but one would not have known that from the look on his face at the time. If one watches the clip, Myers looks frustrated by West and confused by the off-script turn. Solidarity is not the word that comes to mind when looking at the face of Myers in that nationally-televised moment (Grow 2014).

The vast majority of reported hate crimes are not committed by organized hate groups and their members. They are, therefore, hard to track by the Southern Poverty Law Center. Instead, they are committed by teenagers, primarily white males, acting alone or in a group. The NYPD Bias Unit found that 63.84 percent of hate crime offenders were under the age of nineteen. The most common hate crimes are intimidation, vandalism to property, and simple assault (Jacobs \& Potter 1997:19-20). When profiling victims of hate crimes, researchers have found that in general the emotional responses of hate crime victims are the same as that of ordinary crime victims. Only one significant difference in hate crime victims' emotional reactions is that they experience less emotional injury. 'A major difference in the emotional response of hate crime victims appears to be the absence of lowered self-esteem. The ability of some hate violence victims to maintain their self-esteem may be associated with their attribution of responsibility for the attacks to the prejudice and racism of others' (Jacobs \& Potter 1997:31-32; emphasis added). If you are hit by someone for reasons beyond your control, it seems less devastating than if you could have done something to make yourself less vulnerable to the wound. 
The braggadocio in rap might here be seen as the confident rejoinder of a community to the mass hate crimes against people of color: They have hurt us, but they cannot keep us from standing. West shows up to white concert events and white telethons and refuses to be a civil representative of the colonialism that produced his ire. He is at these events a hero to some and a 'jackass' to others (cf. Samuels 2012).

There is a dreary cliché that states, 'One man's terrorist is another man's freedom fighter'. To say this is not to deny the consequences of terrorist actions. It is to realize the heresy that is at the heart of any bid for true bravery. Daniel Cottom argues that 'art cannot be described without raising the issue of misanthropy' and there is 'no way that misanthropy can be described...that will triumph over the question of heresy...art teaches us that we live in the company of misanthropes' (Cottom 2002:129). Kanye has, from the beginning of his career, defined himself as an opposition artist who uses people's dislike of him as a component of his artistic self-creation.

We know now that rap is art, and as a form of art it functions as a form of oppositional culture in the face of institutionalized discrimination, racial formation, and urban decay. The development of resistant stances to domination is never a simple, straightforward process for subordinated groups. Theresa Martinez comments on rap, stating that the relationship between dominant and subordinate groups encourages, enforces, fosters, and even coerces a full continuum of moves, countermoves, negotiations, protests, submissions, struggles, neutralities, alliances, accommodations, and resistances (Martinez 1997:269). As Chidester would describe relations on the African frontier, complex and contradictory relations emerge which result in a web of interactions that make 'resistance' itself a contested arena of discourse.

In recent years, the term 'hate-watching' has been increasingly applied to the thing people do when they consume something in pop culture they do not like, but they keep watching. Early uses of the term focused on watching a television show like Studio 60 on the sunset strip or Smash. Invariably the thing being hate-watched was something about privileged white people; invariably the hate was described as distinct from a guilty pleasure in that the object being hated (while being watched) was not lowbrow but ambitious; invariably the thing being watch with (perhaps self-)hate was a TV series with high ambitions that features a certain amount of aesthetic gloss to the proceedings. Emily Nussbaum, TV critic for the New Yorker, justifies this as an edifying practice: 
Studio 60 was a show that people loved to hate-watch, because it was bad in a truly spectacular way - you could learn something from it, about self-righteous TV speechifying and failed satire and the dangers of letting a brilliant showrunner like Sorkin run loose to settle all his grudges in fictional form (Nussbaum 2012).

Nussbaum here sounds like she is saying that watching something you hate helps you observe excess in general. And given the racial profile I have observed of the use of 'hate-watch', it seems like a monitoring of something inside the viewer, too, that they seek to curb - that Nussbaum is suggesting, by watching Studio 60, she curbs herself in her flights of fancy or excess (Nussbaum 2012).

There is an eerie echo between hate-watching TV and Hatewatch, the investigative unit of the Southern Poverty Law Center that monitors and exposes the activities of the American radical right. When I am watching highconcept television that I know is trying to be good, but I know it is bad, how am I mirroring the work of Hatewatch, which reports on identity extremists, anti-Muslim activists, and a variety of hate crime trials? What Sartre said about the anti-Semite (Sartre 1944), or Fanon about the colonist (Fanon 1961), apply to the despised 'other': If they do not exist, one would have to invent them. Is hate-watching a TV series the effort by a left technocratic elite to conjure the 'other' they must hate (because hate-watching is an inevitable feature of human life)? Added to this: Is that 'other' those who they believe (unconsciously accuse) of perpetuating the aesthetics of white power - the very white power, that (in other hands, in other castes) leads to Tiki torches and hate crime trials, or, in the hands of Chidester, perpetuates the obsessive interpretations of the colonial apparatus? Who hate-watched more than the colonizer looking at the colonized?

Hate groups have established an electronic community of hate through the web, taking advantage of the ease of communication and the possibility of communicating directly, instantaneously, and inexpensively. One of the primary goals of hate groups is to develop a public for their views, to get those views into the mainstream and, perhaps thereby, to make them more acceptable. Experts are increasingly concerned that the rise of hate in cyberspace and on the airwaves will cause people to become more tolerant and accepting of messages that were once considered unacceptable and extreme (Borgeson \& Valeri 2004:101). 
Social psychologists agree that an individual develops an identity in order to provide a sense of cohesion to their life. This can be achieved by focusing one's identity into a singular passion such as power, destruction, or hate. The awareness of the self requires the individual to have an effect on or accomplish something. Social theorist Lauren Langman argues: 'A feeling of powerlessness activates a desire to overcome the feeling of inferiority when one has little effect on others which then leads the self to act aggressively in order to create the desired effect of having control or power over others. Sadism and destructiveness thus empower the self' (Langman 1998:173). When we watch Kanye West, we are watching his empowerment as well as ours. Domination through interruption is not just the act of a jackass - it is a defining feature of colonial persistence.

\section{Whiteness coming}

Sadism and destructiveness in self-building seem clear in the archive of West - it is harder to see in Jordan Smith. What sadism can be found within such a harmless fellow? Bidding for Jordan Smith to choose him as his The Voice coach, Maroon 5 front man Adam Levine told him, 'I think that not just the show, but the world needs a person like you. I think you're the most important person we've ever had on the show' (Showler 2015). A few weeks later, Levine went further: 'You're not a singer - you're a figure. You're a person that everyone draws this amazing energy from. It's unlike anything I've ever experienced in my life, and I'm just honored to be a part of it' (Showler 2015). It is not coincidence that health-and-fitness obsessed Levine transforms doughty Jordan into an icon. A man's relationship with his body reveals the way race shapes masculinity more than any other object of study. Black men, because of their race, never had the luxury of not having their bodies examined. Race is a bodily discourse, and in its, black bodies were viewed as ugly and inhuman and were treated as proof of their inferiority to whites.

As a long chain of scholarship on whiteness and masculinity has shown, white men have fought to align their bodies - ideal, heroic, fit bodies with civilization, and have conducted these arguments not only over black bodies but also over other bodies, like fat bodies, disabled bodies, bodies rendered as 'other' because they're marked as the wrong white ethnic (the Jew, 
the Pole, the Irish). Here Jordan Smith gets lifted up from the scrum of dismissal by Levine as a figure, because his (Jordan's) body is the confusion that proves his spirit. We know Jordan is godlike precisely because nothing else about him is, except, of course, his able whiteness.

Writing about $21^{\text {st }}$-century game shows, David Bosworth has observed that the ultimate prize of these contests is the 'dramatic transformation of one's social and psychological status'. Every game is, at its heart, a simulation of the media's 'fame game' in which the contestants' 'adventure in celebrity' is the central subject (Bosworth 2006:126-127, 128). Deliberating on colonial writings about religion, David Chidester observes that there is no 'real' religion for the colonizers to find, since the 'very terms religions and religions of the world were products of the colonial situation' (Chidester 1996a:16). The only thing scholars can track is the practice of invention 'which knowledge about religion and the religions of the world was fashioned on colonial frontiers' (Chidester 1996a:16). I link the work of Bosworth and Chidester to observe how the process of celebrity-discovery in which Jordan Smith found himself a televised star was not unlike the process of religion-discovery in which African subjects found themselves as relentlessly diagnosed individuals. In both instances, the story concludes when the subject has been squeezed of their freedom; when the star is no longer individuating with spirit and instead submitting to the system. According to Chidester (1996a:26), 'When a frontier closed, indigenous resistance was broken or contained, and European hegemony was more or less established, a religion, or a religious system, was discovered that could be defined and inventoried'.

This is not a racially neutral process. As Chidester explains, colonials established white supremacy throughout Southern Africa by delimiting groups as 'tribes' and sequestering those communities (often through reservation systems) in order to interpret them (Chidester 1996a:26). Richard Dyer argues that racism is not simply the ascription of racial inferiority to non-whites; racism is a detailed assessment procedure in which certain subjects are found to have properties, and others are found not to have it. Dyer demonstrates that whiteness is the organizing, invisible voice: 'The white man has attained the position of being without properties, unmarked, universal, just human' (Dyer 1997:38).

I am suggesting that our attraction to West's unlikability is the other side of our love for Jordan Smith. We love Smith because his voice is a universal whiteness; we dislike West because he would not stop telling us why 
his body, and those with a body like his, are the real thing with which to contend. Smith is the white man whose specific Christianity, conveyed in the gospel songs he performed on a network reality competition, is crafted into our secular safety. Who could imagine this person could do anything else but wish us all well?

The title of this essay, Can't help lovin', is taken from one of the more famous songs in the Jerome Kern and Oscar Hammerstein 1927 musical Show boat. The song, written in a blues tempo, is sung in the show by several characters, but is most closely associated with the character, Julie, the leading lady of the titular show boat 'Cotton Blossom'. In the musical's plot, the song is supposed to be familiar to African Americans for years, and this provides one of the most dramatic moments in the show. When Queenie, the black cook, comments that it is strange that light-skinned Julie knows the song because only black people sing it, Julie becomes visibly uncomfortable. Later, we learn that this is because Julie is 'passing' as white - she and her white husband are guilty of miscegenation under the state's law. She can't help lovin' in two ways: She cannot help that she loves this music, and she cannot help the race that she loves. She is drawn to certain things, certain sounds, and certain communities of songs, and she knows that being drawn to this African American song is what will, eventually, expose her. Humming with black workers, humming to herself, she will be seen for her desire. The music shows the truth of what she is, how she likes the very thing that could exile her from her audience's liking.

\section{Christian universalism}

In the history of hate-watching, there is perhaps no greater hate-watcher than Theodor Adorno. He hated a lot of things and a lot of popular music, because he felt it fell short of its aspirational ideal to unify society through meaningful reconciliation. He watched things he hated to understand how music works, and how bad things could be appealing. For him, music was only good if it could reproduce, in its inner relations, the possibility of individuals changing and being changed by each other in socially productive relations from which a social whole or totality is always emergent. He listened to bad music to understand good music, to understand what kind of music, oriented toward 
reconciliation, could lead toward the production of a larger, more inclusive whole (Witkin 2000:148).

David Chidester has no apparent normative vision for the good a form of culture could do. He was not disinterested in wholes; however, he was as intrigued as Adorno in the possibility of a space of communion. Following Durkheim, he calls such commons 'church'. In his work on popular culture, Chidester looks for institutions that maintain 'the continuity, uniformity, sacred space, and sacred time of American life'. In his work on African colonialism, Chidester does not look for churches. In that geography, he looks instead for the tug-and-pull of defining religion as a tool of imperial social discipline. Something about American popular culture allows him a space to describe a common - he finds it in baseball (Chidester 1996b:745).

Jordan Smith's octave-bending version of Beyoncé's Halo prompted The Voice judge Pharrell Williams to tell the singer: 'Literally, it's totally true that God has signed your voice'. Gwen Stefani jumped in to concur: 'All I can think of is God when he sings' (Showler 2015). And Adorno would say: 'You have got to be kidding me'. He would listen to Smith and say: 'You think this is reconciliation, but this is just part of your bourgeois self-deception'. Adorno believes that the claim to reconciliation is a lie in that the bourgeois society never did meet these conditions in reality; quite the contrary. He would have dismissed Pharrell Williams and Gwen Stefani's praise of Jordan Smith as sheer ideology, while Chidester would have seen in Smith a settler frontier figure - someone who heard the native songs and loved them, just loved them.

It must be made clear that Jordan Smith is consistently portrayed as an exceptional figure on The Voice. Although others testify to church pre-histories and Christian feelings, only Smith is so physically non-normative as to command from viewers a regular sympathy. His exceptional aesthetic presentation becomes his point of entrance into the multiculturalist frame of contemporary mass media in which every figure has to sell a story of disidentification - to borrow from the work of José Esteban Muñoz (1999:25) in order to seem like one of the gang. Every participant in a show needs to mark themselves as distant from the presumptively normative audience (white, heterosexual, middle class) so that regular Americans can imagine them as a hero rather than grossly-fortunate Eddie Haskell's heel. Thomas Sarmiento has written in reference to the TV series, Glee, that 'superficial representations of social difference have become the new normal' (Sarmiento 2014:213); and Muñoz argues that 'disidentification can be understood as...the hermeneutical 
performance of decoding mass, high, or any other cultural field from the perspective of a minority subject who is disempowered in such a representational hierarchy' (Muñoz 1999:25). Yet this disidentification with the norms of American society do not diminish its sway. If anything, such a disidentification only lays bare the traces of empire: As every contestant and guest star and public figure needs to distance themselves from a normative middlebrow whiteness, this very whiteness is only affirmed as the dominating structure of our self-interpellation (Sarmiento 2014:229).

\section{Concluding cracks}

In this essay I aimed to expose how this realization of the settler compulsion to religion is not only a definitional project of diagnosis, but also an affective feeling that drives us into our contemporary cultural consumptions.

I am wary, of course, that making any single diagnosis of culture only affirms a clarity that Chidester worked hard to undermine with his repeated observation of 'reciprocal exchanges, creative interchanges, and unexpected possibilities' (Chidester 1996a:266). Chidester is not alone in his effort to diffuse any grand theorizing of culture. The great historian of black expressive culture, Lawrence Levine, once wrote that 'popular culture does not present us with a single face or an orderly ideology...one has to look not for an unvarying central message but for patterns of meaning and consciousness across the genres and among different segments of the population' (Levine 1992:1399). Even then, he argues, will we have to deal with the fact that 'whatever patterns we find exist alongside the inconsistencies, tensions, and cacophony of voices that help, far more than any putative unanimity and harmony, to reveal [our] cultural complexity' (Levine 1992:1399). Levine and Chidester sound like interpretive kindred. To be a historian is to know that worries is variable, filled with crevices. Can we retain the historian's sense of multiplicity alongside Adorno's adjudication of bourgeois self-deception?

To be clear, Adorno remains true to that ideal in the face of the impossibility of its realization in the late capitalist society. He loves the music, even though most of it is worth his, or our, hate. Watching Jordan Smith with Chidester and Adorno allows us to ask if this is all the art settler frontiers can afford. Will we always have some things we like and some things we do not, 
and will those always be mapped racially? Will the things we like always be borrowing from blackness and will the things we do not like always be demonstrating its frontier threat? Social media has provided a prime testing field for a longstanding subject of religious studies interest, namely that of mimesis. It is said that one's personality is the average of their five closest friends, but when it comes to Twitter, the people one follows determine how they act. According to researchers at Indiana University, Twitter users tend to tweet in line with the emotions expressed by the people they follow. Therefore, any angry, hateful, or negative Twitter users one follows, make them more likely to tweet similar sentiments. Users who are exposed to a disproportionate number of negative tweets are more likely to post negative messages on the social network, and the effect is even greater with positive tweets, the researchers found, terming the effect 'emotional contagion' (Ferrara \& Yang 2015).

This research reiterates what theorists of religion have already explained, namely that people can go crazy in congregations. This is why there is no pure artist (no pure art) that cannot be prone to the slide of emotional contagion. Hip-hop cannot save us any more than the judges on The Voice can save their contestants. Each of these forms is just another bid for creation, engagement, exchange, and seeing. Kanye West, like almost everyone in hiphop, is prone to the gender paradigm of his self-promotions and the ignorant pomposity of the monomaniacal artist. Rap can seem to endorse nonhegemonic modes of embodiment, but it also is in service of the hegemonic goals of controlling women and displaying capitalist success (Randolph 2006:200-217). Once again, Stuart Hall gets to the crux of the matter:

If the global postmodern represents an ambiguous opening to difference and to the margins and makes a certain kind of decentering of the Western narrative a likely possibility, it is matched, from the very heartland of cultural politics, by the backlash: the aggressive resistance to difference; the attempt to restore the canon of Western civilization; the assault, direct and indirect, on multiculturalism; the return to grand narratives of history, language, and literature...[and] black popular culture is not exempt from that dialectic (Hall 1993:107). 


\section{Kathryn Lofton}

Kanye West exemplifies this dialectic: He used the opening pop culture provided to forge new spaces of expression; he also used his bully pulpit to reject people's idea of his assimilation. In 2018, West returned to the public sphere after a brief hiatus, supposedly fueled by a mental health crisis. His reappearance included a new album, simply titled ye, and a firestorm of Tweets in which he showed respect for President Donald Trump and claimed that slavery was a choice. Longtime fans of West did not see so much incongruity in these social media moves - not only because West is a provocateur who knows how to sell an album through the adventure of his celebrity; not only because he has a long history of disrupting our comfortable expectations of media forms; not only because he has rapped before about free-thought, slavery, and his general resistance to our liberal pleasure; but also, as Ta-Nehisi Coates states, because West knows his pop culture colonialism:

There is no separating the laughter from the groans, the drum from the slave ships, the tearing away of clothes, the being borne away, from the cunning need to hide all that made you human. And this is why the gift of black music, of black art, is unlike any other in America, because it is not simply a matter of singular talent, or even of tradition, or lineage, but of something more grand and monstrous. When [Michael] Jackson sang and danced, when West samples or rhymes, they are tapping into a power formed under all the killing, all the beatings, all the rape and plunder that made America. The gift can never wholly belong to a singular artist, free of expectation and scrutiny, because the gift is no more solely theirs than the suffering that produced it (Coates 2018).

There is no pop power without colonial power; there is no colonial power without religion. Chidester's theory for the study of religion is one in which we are not allowed to forget the conjunction of pain and play that defines our entertainments and organizes our churches. 


\section{References}

Agawu, K. 1992. Representing African music. Critical Inquiry 18, 2: 245-266. Alessandro, R.C. 2013. Kanye West interrompe Taylor Swift no VMA 2009. YouTube. Available from: https://www.youtube.com/watch?v= RvaakT52RjQ. (Accessed on 12 January 2018.)

Berzock, K.B. \& C. Clarke (eds.) 2011. Representing Africa in American art museums: A century of collecting and display. Seattle: University of Washington Press.

Beyoncé. 2009. Single ladies (put a ring on it). YouTube. Available at: https://www.youtube.com/watch?v=eREH27Zc7NY. (Accessed on 12 January 2018.)

Borgeson, K. \& R. Valeri 2004. Faces of hate. Journal of Applied Sociology 6, 2: 99-111.

Bosworth, D. 2006. Auguries of decadence: American television in the age of empire. Salmagundi 152: 126-127; 128.

Chappell, B. 2010. 'Bush says Kanye West's attack was low point of his presidency; West agrees'. NPR, 3 November 2010. Available at: https://www.npr.org/sections/thetwo-way/2010/11/03/131052717/ bush-says-kanye-west-s-attack-was-low-point-of-his-presidency.

(Accessed on 12 January 2018.)

Chidester, D. 1996a. Savage systems: Colonialism and comparative religion in Southern Africa. Charlottesville: University Press of Virginia.

Chidester, D. 1996b. The church of baseball, the fetish of Coca-Cola, and the potlatch of Rock ' $n$ ' Roll: Theoretical models for the study of religion in American popular culture. Journal of the American Academy of Religion 64, 4: 743-765.

Chidester, D. 2005. Authentic fakes: Religion and American popular culture. Berkeley: University of California Press.

Chidester, D. 2012. Wild religion: Tracking the sacred in South Africa. Berkeley, Los Angeles: University of California Press.

Chidester, D. 2014. Empire of religion: Imperialism and comparative religion. Berkeley: University of Chicago Press.

Chidester, D. 2018a. World religions in the world. Journal for the Study of Religion 31, 1: 41-53.

Chidester, D. 2018b. Religion: Material dynamics. Oakland: University of California Press. 
Coates, T. 2018. 'I'm not black, I'm Kanye'. The Atlantic, 7 May 2018. Available at: https://www.theatlantic.com/entertainment/archive/2018 /05/im-not-black-im-kanye/559763/. (Accessed on 12 January 2018.)

Cottom, D. 2002. To love to hate. Representations 80, 1: 119-138.

Dyer, R. 1997. White. New York: Routledge.

Earle, T.F. \& K.J.P. Lowe (eds.) 2010. Black Africans in renaissance Europe. Cambridge: Cambridge University Press.

Fanon, F. 1963. Wretched of the earth. New York: Grove Press.

Ferrara, E. \& Z. Yang 2015. Measuring emotional contagion in social media. PLOS ONE 10, 11. Article ID e0142390.

Grow, K. 2014. Mike Myers supports Kanye West's Katrina statement, years later. Rolling Stone, 22 May 2014. Available at: https://www.rollingstone.com/culture/culture-news/mike-myers-supports-kanye-westskatrina-statement-years-later-81099/. (Accessed on 12 January 2018.)

Hall, S. 1993. What is this 'black' in black popular culture? Social Justice 20, 1/2: 104-114.

Haskell, D.M., K. Paradis \& S. Burgoyne 2008. Defending the faith: Easter sermon reaction to pop culture discourses. Review of Religious Research 50, 2: 139-156.

Hechter, M. 1975. Internal colonialism. Berkeley: University of California Press.

Jacobs, J.B. \& K.A. Potter 1997. Hate crimes: A critical perspective. Crimes and Justice 22, 1-50.

Kreps, D. 2009. Kanye West storms the VMAs stage during Taylor Swift's speech. Rolling Stone, 14 September 2009. Available at: https://www.rollingstone.com/music/music-country/kanye-weststorms-the-vmas-stage-during-taylor-swifts-speech-83468/. (Accessed on 12 January 2018.)

Langman, L. 1998. I hate, therefore I am. Social Thought \& Research 21, 1/2: 151-183.

Levine, L. 1992. The folklore of industrial society: Popular culture and its audiences. American Historical Review 97, 5: 1369-1399.

Martinez, T.A. 1997. Popular culture as oppositional culture: Rap as resistance. Sociological Perspectives 40, 2: 265-286.

Muñoz, J.E. 1999. Disidentifications: Queers of color and the performance of politics. Minneapolis: University of Minnesota Press. 
Nowatzki. R. 2010. Representing African Americans in transatlantic abolitionism and blackface minstrelsy. Baton Rouge: LSU Press.

Nussbaum, E. 2012. Hate-watching 'Smash'. The New Yorker, 27 April 2012. Available at: https://www.newyorker.com/culture/culture-desk/hatewatching-smash. (Accessed on 12 January 2018.)

Racy, A.J. 2016. Domesticating otherness: The snake charmer in American popular culture. Ethnomusicology 60, 2: 197-232.

Randolph, A. 2006. 'Don't hate me because I'm beautiful': Black masculinity and alternative embodiment in Rap music. Race, Gender \& Class 13, 34: 200-217.

Samuels, D. 2012. American Mozart. The Atlantic, May 2012. Available at: https://www.theatlantic.com/magazine/archive/2012/05/americanmozart/308931/. (Accessed on 12 January 2018.)

Sarmiento, T.X. 2014. The empire sings back: Glee's 'queer' materialization of Filipina/o America. MELUS 39, 2: 211-234.

Sartre, J.-P. 1944. Anti-Semite and Jew. New York: Schocken Books.

Showler, S. 2015. The Voice from above. Slate, 14 December 2015. Available at: https://slate.com/culture/2015/12/god-religion-and-jordan-smith-onthe-voice.html. (Accessed on 12 January 2018.)

Stanko, E., V. Kielinger, S. Paterson, L. Richards, D. Crisp \& L. Marsland 2003. Grounded crime prevention: Responding to and understanding hate crime. In Kury, H. \& J. Obergfell-Fuchs (eds.): Crime prevention: New approaches. Mainz: Weisser Ring.

Swift, T. 2009. You belong with me. YouTube. Available at: https://www.youtube.com/watch?v=VuNIs Y6JdUw. (Accessed on 12 January 2018.)

The Voice 2015. Jordan Smith - Chandelier, Full Blind Audition. YouTube. Available at: https://www.youtube.com/watch?v=qMK4NsiNmYc. (Accessed on 12 January 2018.)

Tsay, C.-J. 2013. Sight over sound in the judgment of music performance. Proceedings of the National Academy of Sciences of the United States of America 110, 36: 14580-14585.

West, K. 2006. Bush doesn't care about black people. YouTube. Available at: https://www.youtube.com/watch?v=zIUzLpO1kxI. (Accessed on 12 January 2018.)

Witkin, R.W. 2000. Why did Adorno 'hate' Jazz? Sociological Theory 18, 1: 145-170. 
Kathryn Lofton

Kathryn Lofton

Religious Studies, American Studies, History, and Divinity

Yale University

kathryn.lofton@yale.edu 